\title{
Productive Nation? Museums, Cultural Policy and Australia's Productivity Narrative
}

lan McShane* RMIT University

\begin{abstract}
This article traces the emergence of productivity as a central theme in Australia's national cultural policy, and discusses some implications of this development for the Australian museum sector. The analysis focuses on two texts - Australia's two national cultural policies, Creative Nation (1994) and Creative Australia (2013) - to highlight changing policy rhetorics through which cultural heritage and cultural pluralism lose traction, and productivity, innovation and creativity find favour. The article argues that the government's concern to boost sources of economic growth in twenty-first century Australia focus cultural policy on the arts and creative industries, seen as the locus of innovation and the wellspring of creative activity. The article argues against this narrow construction of productivity and its sources, showing why museums are important contributors to a productivity policy agenda in a culturally diverse and globalized society.
\end{abstract}

Key words: cultural policy, Australia, creative industries, productivity, diversity

'A creative nation is a productive nation', Creative Australia - National Cultural Policy, 2013

\section{Introduction}

This article traces the emergence of productivity as a central theme in Australia's national cultural policy, and discusses ways that Australia's historical and cultural museums can work within this policy setting. The governance of publicly-funded cultural activities can be traced from the early nineteenth century (Throsby 2006, Gibson 2001, Rowse 1985). However, the Australian government has released only two comprehensive cultural policies, understood here to mean principles and resource allocation concerning cultural goods: Creative Nation (Department of Communications and the Arts (DOCA) 1994), and Creative Australia (Australian Government 2013). Creative Nation was a path-breaking exercise that sought to foster what it saw as a distinctively Australian cultural identity in the context of Australia's changing cultural makeup, and changing global cultural forms and economies. As discussed below, analysis of the tensions inherent in Creative Nation's claim to be an economic policy as much as a cultural policy (Bennett 2001, Stevenson 2000) echoed a key criticism of the cultural industry concept. Notwithstanding, this article views Creative Nation as broadly sympathetic to the agenda of Australian museums in the late twentieth century, particularly in regard to their embrace of cultural diversity and new audience engagement. However, the conceptual underpinnings and policy focus of Creative Australia, first glimpsed in a 2011 discussion paper, alarmed some in the Australian museum sector. ${ }^{1}$ Sector advocates diagnosed that the discussion paper's neglect of museums signalled they were 'slipping through the cracks' of government policy (Message 2011). In the words of a sector representative, "museums ha[d] long "delivered" across a huge range of government policy portfolios' (Message 2011:203), but the role and purpose of museums was so broad that responsibility was spread over several portfolios and easily marginalized within each. Message (2011) observes the awkward engagement of Australian museums with policy themes of social cohesion and productivity that underpinned 
Labor governments from 2007. This article complements Message's focus on social cohesion and citizenship by discussing productivity as a key policy discourse.

Policies can be understood as stories or narratives of government (Ball 2007; Fischer 2003). I argue that Australia's productivity narrative, and its particular framing in Creative Australia, has marginalized museums, presenting them with the task of garnering support for their distinctive institutional responsibilities and capacities in a new and, for some, hostile policy environment. In detailing this argument, I suggest that Australian historical and cultural museums (art galleries have long been viewed as a separate sector in Australia, and are not discussed here) came to occupy an important niche in late twentieth-century social and cultural policy, as renovators of a settler-colonial story to be more inclusive of Indigenous, migrant and environmental perspectives. Australia was one of the first nations in which museums promoted cross-cultural understandings in a context of culturally diversifying populations. However, policy responses to broad structural trends characterized as the culturalization of the economy (Flew 2012; du Gay and Pryke 2002; Lash and Urry 1994), shifted policy emphasis away from cultural dialogue to increasingly focus on cultural industries, with the subsequent iteration of the creative industries reinforcing (or for some transforming, see Potts and Cunningham 2008) the culture-economy nexus. In each of these perspectives, museums, and cultural institutions generally, are viewed through new economic lenses, and publicly funded institutions ignore this at their peril.

As an exercise in policy rhetoric, Creative Australia is in good company. Productivity is a key driver of recent public policy in Australia and elsewhere. In this article, though, I argue that the museum sector has not engaged with productivity's influence on cultural policy. The literature on cultural policy is extensive and multi-faceted, and space here permits only a brief exploration. Criticism of the economic turn in cultural policy has largely focused on the threat it poses to the arts. The burden of this criticism is that prioritising economic value in the arts and cultural industries 'risks undermining the very distinctiveness through which this value can be generated and legitimized' (Banks and O'Connor 2009:370). This article follows O'Connor's (2009) defence of cultural and economic rationales for cultural funding. From this standpoint, this article argues that museums - whose profile has been slight in this debate - can make a pragmatic and distinctive contribution to the key concepts of innovation and productivity that will strengthen the framing of those concepts within policy, while advancing an important theme in Australian museology.

The article proceeds as follows: the next section discusses the conceptual makeup and emergence of productivity as a central policy narrative in Australia. Here I argue that cultural policy is not sui generis, but is shaped by wider ideological, bureaucratic and communicative frameworks of governance. Following an overview of the historical development of cultural policy at a national government level in Australia, I then analyse the text and context of the two policy documents under scrutiny to show the elevation and meaning of a cluster of terms I describe as the productivity narrative. This discussion, particularly the changing discursive construction of the texts, is illustrated by Table 1, which contains a selection of keywords from both texts and shows a sharpening focus on the language of productivity, innovation and creativity. The article concludes by discussing rationales and conceptual tools for museums to expand current policy understandings of innovation and productivity.

The article's conceptual and methodological frameworks are influenced by a postpositivist epistemology, particularly its application to policy analysis as seen, for example, in the work of the environmental policy scholar Frank Fischer (Fischer and Gottweis 2012; Fischer 2003), and the educationalist Stephen Ball (2007). This epistemology turns away from a formalist approach to policy making (the 'policy cycle') to focus on the mediating role of language and communication in constructing and telling policy 'stories'. Methodologically, this approach draws on historical, institutional and discourse analysis to reveal the trajectory of policy, the networks through which it circulates, and the language and discursive techniques through which policy stories are told (Ball 2007). 


\section{The Productivity Narrative}

In contemporary Australia, productivity has become a dominant political catch-phrase. Concerns over productivity have underpinned recent policy formation and institutional frameworks at all levels of Australian government, but particularly at national level (Garnaut 2013, Daley 2012). Economic productivity and competitiveness have been policy drivers of Australian governments of both social democratic and conservative flavour in recent decades, notably through the work of the Council ofAustralian Governments, the chief coordinating mechanism of Australia's federal system of government. The transformation in 1987 of the protectionist Industries Assistance Commission into the free market Productivity Commission was a turning point in Australia's political economy, and since that time an expanding range of government programmes (including heritage, see Productivity Commission 2006) have come under the Productivity Commission's market-liberal analysis. Supporting Message's (2011) claim, Labor governments from 2007 have been particularly concerned with labour productivity, evidenced through measures such as the rebadging of Skills Australia, an advisory body on the skill and training needs of the Australian workforce training, as the Australian Workplace and Productivity Agency.

Productivity is most simply defined as given output per unit of input, with labour productivity - the output of each worker over a unit of time - the most common productivity measure. So-called multifactor productivity, which combines labour, materials and capital, is generally accepted as a more comprehensive measure of output changes within economies. As the Productivity Commission observes, labour productivity is comparatively high in Australia, with the productivity of materials and capital dragging Australia's economic performance down. ${ }^{2}$ Economic theory holds that productivity growth is the major determinant of a country's standard of living. Krugman neatly expresses the policy dilemma posed by this materialist conception - productivity isn't everything, but in the long run it's almost everything (cited in Garnaut 2013:130).

Determinants of productivity growth include investment in factors of production, such as physical and human capital, and innovation through technical developments or new business processes. Innovation has seized the policy high ground in recent years, spurred on by information and communication technologies (ICTs) and the digital economy. Concern over the relative productivity of different industry sectors within national economies reflects the fact that some industries, particularly those in manufacturing sectors with access to technological and process improvements, outpace others in productivity growth. This insight was famously applied to the performing arts by US economists, William Baumol and William Bowen (1966), in a book credited as a foundation text of cultural economics (Heilbrun 2003). In a thesis pejoratively known as Baumol's cost disease - the pathological metaphor is revealing - Baumol and Bowen argued that while the wages of musicians rose comparable to the rest of the economy, there was little capacity to increase their labour productivity. A Beethoven string quartet, they argued, required the same labour input in 1966 as it did in 1800. Other sectors of the economy, education for example, with high labour input and 'production' processes that have changed little over time, are subject to similar diagnoses (KPMG Econotech 2011). The cost disease thesis has attracted criticism, particularly for its failure to account for the impact of technological change (Potts 2014). Nevertheless, it has been influential in forming negative associations between productivity and cultural activities, and supporting a neo-classical marketfailure or public-goods rationale for cultural funding.

By contrast, Potts (2011) distinguishes between a standard, equilibrium model of cultural economics, in which public resources are allocated to correct market 'failures' and realize the welfare gains of cultural consumption, and a creative industries model, grounded in Schumpeterian notions of disruptive change and innovation. The dynamic efficiency or longrun impact of this open system has produced major innovation and productivity gains in areas such as digital technologies and the creative and cultural goods produced and distributed with these technologies, he argues.

As detailed below, the creative industries model has been highly attractive to policymakers internationally, particularly in emphasizing innovation and intellectual property outputs. In Australia, creative industries have a special appeal as Australia's terms of trade decline in a post-resource boom era. However, to recap the argument so far, while productivity has become 
an important objective of Australian cultural policy, it has also been narrowly conceptualized and applied. Before tracing this trajectory through the two texts under review, I set the scene by briefly outlining the history of national cultural policy making in Australia.

\section{Towards a National Cultural Policy in Australia}

National governments face a difficult task in delineating the parameters and objectives of a policy field that is increasingly global in its influences and settings, while increasingly deployed by sub-national jurisdictions, especially cities (Grodach and Silver 2013). Additionally, in Australia's federal system, state or provincial governments have considerable responsibility for cultural programmes, and state governments have been enthusiastic proponents of cultural policy reform. However, as Craik et al. (2003) argue, national governments are still powerful players in cultural policy formation. Arguably, the Australian federal government's role in the cultural policy field has been enhanced in recent years through its regulation of telecommunications and media ownership and content.

The development of a cultural policy appears to have first been discussed by the Australian government around 1970. National funding for cultural activities - mostly directed to literature, the performing arts and the visual arts - was fragmented across several ministerial portfolios, and in 1971 the conservative Liberal-Country Party coalition government established an arts ministry to bring coherence to this situation. However, the first national arts minister, Peter Howson, soon began to think about the normative underpinnings of policy. He records discussing with parliamentary colleagues that a 'general policy for the arts could be a theme by which we produce a national identity' (Macdonnell 1992:56).

Museums and cultural and natural heritage became increasing objects of national policy attention under the reforming and nationalistic Whitlam Labor government (1972-1975). National approaches to policy-making in the cultural sphere have alternated between impulses towards centralization (generally favoured by Labor governments) and decentralization (an emblematic conservative approach). In the late twentieth century, both major national political groupings in Australia, Labor and the Liberal-National (formerly Country Party) coalition, included arts and heritage policies in their election platforms. However, in contrast to Howson's stance in 1971, conservatives have since been wary of a national cultural policy, as representing a centralization of power and a suggestion that culture might somehow be subject to government edict (Caust 2015).

To some extent, the Labor government led by Paul Keating (1991-1996) shared that view: 'few would maintain that governments can or should create culture or national identities' (DOCA 1994:9). However, consistent with the focus on structural and economic reform that was a feature of national Labor governments between 1983 and 1996, the Keating government saw the early 1990s as a period of technological change and cultural dynamism that required strong policy direction. Digital media platforms, the government argued, were revolutionizing cultural production and consumption, but key cultural sectors such as broadcasting lay outside the culture ministry. In 1993 the Keating government reorganized portfolio arrangements by combining broadcasting and communications together with arts and heritage in a new Department of Communications and the Arts. Then, after two years of deliberation, the government released Creative Nation.

\section{Framing National Cultural Policy - Creative Nation}

Creative Nation argued a case for greater recognition of an Australian culture that had been distinctively shaped by the population's diverse backgrounds and cultural outlooks. This development had been underway in Australian museums for several decades, beginning in the 1960s with the establishment of small ethno-specific museums promoting the cultural heritage of Baltic nations that had fallen under Soviet rule. ${ }^{3}$ In the 1980s the Australian museum sector engaged with the emergence of multiculturalism as a core social policy, through new ethno-specific or migration themed museums, and more inclusive approaches to collecting and programming. This development was not exclusive to museums (see Hawkins 1993 on multiculturalism and the arts), but exerted a strong influence on the museum sector's institutional 
profile and programmes. In 1991, when the national government issued a policy document titled A Plan for Cultural Heritage Institutions to Reflect Australia's Cultural Diversity (Consultative Committee on Cultural Heritage 1991), there was little fuss within the sector. Museums - at least major metropolitan ones - were pursuing pluralist collecting and exhibition practices, and exploring new ways of engaging communities in museum making. At the same time, a conversation about diversity itself was taking place. Did the concept extend beyond ethnicity to include gender, sexuality, other perspectives? How did the discourse of multiculturalism relate to representations of Indigenous culture and the objections of some Indigenous people to incorporation within a multicultural story? What place was now accorded to the experiences and cultural expressions of the settler-colonial population? And how should museums respond to an emerging debate that Australian multiculturalism was itself a historical artefact, situated within a particular political context and subject to contested views on whether it entrenched political and cultural hegemony (Hage 1998), or promoted cultural fragmentation (Hodge and O'Carroll 2006)?

Creative Nation entered this debate by emphasizing cultural pluralism and cultural rights: 'we are genuinely and distinctly "multi-cultural" with meanings that extend beyond ethnic diversity... our cultural heritage must be accessible to all Australians...collections and exhibitions [must] adequately represent the culture and values of diverse groups in our society' (DOCA 1994: 9,75). However, if Australian culture was enriched by global population flows, it was, in Creative Nation's view, also threatened by global mass culture. Cultural institutions needed to position and promote Australian stories in a rising sea of global content, the document argued. New media, in particular, offered new ways to reconcile long-standing policy conflicts between excellence and access, they could overcome the tyranny of distance in Australia, and they could open new markets for Australian content.

Creative Nation was alert to the economic potential of new cultural 'products', particularly digital media. Australia's integration with a global cultural marketplace opened trade opportunities, and the policy gave considerable attention to fostering the emergence of an 'interactive multi-media industry' built on a CD-Rom platform, which the policy saw as an intermediate technology that would be superseded by online products. However, the document also argued that culture required a policy frame that looked beyond 'efficiency and productivity' (DOCA 1994:55). Australian cultural institutions were urged to get their products onto the 'information highway', but also to 'invigorate the national life and return its product to the people' (DOCA 1994:9).

In emphasizing Creative Nation's economic instrumentalism, commentators have placed weight on its introduction of the term cultural industry to Australian government policy. The term was circulating in UK Labour-led local governments as a policy driver of urban and economic regeneration (Pratt 2005). There were Australian precursors, though, such as the Industries Assistance Commission's (1976) inquiry on the performing arts and the Australian government's arts funding body, and the Australia Council of the Arts framing of submissions in 'industry' terms during the 1980s (Glow and Johanson 2006). The term cultural industry was a useful container for an expanding policy field, and it was a short step for a government with a fondness for industry plans in the manufacturing sector to apply this conception to the cultural sphere. However, in its first pages Creative Nation sets out a conventional view of culture, as 'the expression of a society's aesthetic, moral and spiritual values', speaking in transcendent tones of culture's responsibility for the transmission of heritage and civilization, the ennobling of human existence, and the expression of an Australian spirit (DOCA 1994:2). As commentators noted, here was a colourful palette of policy positions: an industry analysis that saw culture in economically instrumental terms, a defence of culture's intrinsic value, and an acknowledgement of dynamic cultural identities in a pluralist society. ${ }^{4}$

\section{From Cultural to Creative Industries}

In March 1996 the Keating government was defeated in a national election by the Liberal/National coalition led by John Howard. As Paul Keating once observed, change the government and you change the country. ${ }^{5}$ Culture soon became a political battleground, spurred by Howard's view that 'as a nation we are over all that identity stuff' (Throsby 2006:19). 
The Howard government sought to instate a more culturally uniform and univocal narrative of Australian society and its past. Strategies included the government's disavowal of multiculturalism as a foundation of social policy, the inception of a new test of cultural knowledge for citizenship applicants, a review of the newly opened National Museum of Australia, and the refusal to sign the 2005 UNESCO Convention on the Promotion and Protection of the Diversity of Cultural Expressions. However, the Howard government also agreed with significant parts of the Keating government's cultural policy (Caust 2015). Creative Nation's concern over the dangers to Australia posed by a flood of global digital content was echoed in the Howard government's development of a strategy for the digital economy. Within this frame, collecting institutions were viewed for their resource potential, with policy rhetoric suggesting they 'unlock' their collections for market availability. During the Howard government (1996-2007), Australian cultural institutions did indeed place greater emphasis on digitization and web programming, encouraged by specific national government funding programmes (particularly for school curriculum materials), by the rapid development of web technologies, and by increased internet connectivity across the population. By the early 2000s, virtual visits to large collecting institutions were easily surpassing physical visits (McShane and Thomas 2010).

In the late 1990s an important shift occurred in this policy field, impelled initially by internal UK Labour politics, and transferred to Australia through a pattern of international policy transfer evident in the cultural sphere. As Garnham (2005) and Pratt (2005) recount, a significant part of the Blair New Labour government's modernizing crusade involved recasting cultural industries, associated with Old Labour strongholds in unions and local government, as creative industries. The most significant aspect of this change, for some, was the inclusion of the computer software sector within the new rubric of creative industries. Garnham (2005) argues that this move, along with continued use of the term industry, bracketed cultural and software sectors within a broader conceptualization of the information or knowledge society, justifying claims for the creative sector's economic significance. However, this move also subordinated what Garnham calls the aesthetic claims of arts and culture to a policy outlook that saw innovation-driven productivity and growth as a major objective (see also Oakley 2009; 2004). Critics of this 'narrative of benign convergence' (Banks and O'Connor 2009:366) also pointed to its uniform prescription for the social and economic woes of declining regions, the vague boundaries and lack of hard evidence of the economic contribution of the creative industries, and the romanticization of precarious creative labour (O'Connor 2009; Oakley 2009; Gill and Pratt 2008). The re-conception of cultural industries as creative industries was welcomed by other commentators, who rejected the opposition of economic and cultural values in favour of an emergent system in which technological innovation, specifically convergent digital media and networked computing, produced new economic and cultural values, and new patterns of production and consumption (Cunningham 2009; Hartley 2005). The re-conceptualization of creative industries as markets (where social networks influence novelty and innovation), in opposition to a prevailing industry model (in which a sector is defined by creative inputs and intellectual property outputs), elaborates this development in micro-economic terms (Potts and Cunningham 2008; Potts et al. 2008). This development drew renewed criticism of the neoclassical roots of the creativity that is operationalized within the creative industries (Miller 2009).

As Garnham pointed out, there are many continuities and disjunctions in this story, which cannot be fully explored here. It is important to note, though, the rapid momentum that innovation gathered as a policy objective within and across governments at this time. Policy settings to encourage links between creativity, innovation and productivity were explored in several countries. ${ }^{6}$ When the Rudd Labor government came to office in Australia in 2007, it established a portfolio department of innovation and commissioned a review of Australia's 'national innovation system' (Cutler and Company 2008). This review broke new ground in locating Australian cultural agencies within the innovation system, a concept that had been theorized in the mid-twentieth century but largely focused on science and technology. The review's report, VenturousAustralia, uses the term 'creative industries' only once, preferring to identify and address the distinctive roles of the arts sector, collecting institutions, and media. The arts and media sectors, said the report, rely heavily on innovation in producing $\$ 50$ billion of cultural products and services annually. The 'cultural and collecting agencies' played a different role. Their economic contribution was staked on their significance for the formation of 
human and creative capital. The report argued that funding models and institutional mandates should recognise the research and innovation role and contributions of cultural agencies and institutions responsible for information repositories, physical collections or creative content and fund them accordingly. (Cutler and Company 2008:96)

The report argued that Australian society is not simply of a stock of human capital, but a diverse mixture of cultural outlooks and competencies:

The country's unique ethnic population diversity underpins that pluralism which is important to creativity and innovation and also creates global cultural connections that are, perhaps, not leveraged as much as they might be. (Cutler and Company 2008:42)

Where VenturousAustralia recommended that collecting institutions be included and funded within the national innovation system, a competing policy vision was advanced through the Rudd government's Australia 2020 Summit. This much-publicized convention of politicians and invited participants held in 2008 was designed to 'help shape a long term strategy for the nation's future'. ' 'Productivity' was the first of the summit's ten discussion themes, but the theme especially concerning us here was titled 'Towards a Creative Australia - the Future of the Arts, Film and Design'. The conceptualization and discussion of this theme drew on a long-standing tendency for the arts to stand in for a wider set of cultural activities, and applied creativity to a particular quadrant of the cultural industries. There were few museum advocates amongst the ninety or so participants in this theme, with attention in the 'Major Galleries and Institutions' session oriented towards the art sector. Where the wider library, museum and gallery sector had drawn sustenance from VenturousAustralia, the Australia 2020 Summit was bitter bread indeed.

\section{Reframing National Cultural Policy}

2009 was an inauspicious year to begin preparation of a new national cultural policy. The Australian government's response to the 2008 global financial crisis and plans for a national broadband network engaged senior ministers' attention. The culture minister, former rock star Peter Garrett, became embroiled in controversy in another area of his portfolio, relating to a roof insulation scheme, that eventually cost him his job. Nonetheless, the sense that a revision of existing cultural policy settings was long overdue was palpable (Caust 2015). The development process followed Creative Nation's lead by assembling an 'expert group' of cultural practitioners and advisers to give initial shape to the policy. The process was then thrown open for wider consultation via a web blog, before a ministerial reshuffle, leadership challenge and change of Prime Minister, and a national election took over. The Labor Party's 2010 election platform resonated with the Australia 2020 Summit, with a platform paper titled Investing in a Creative Australia focused on 'what Labor [is] doing for the arts' (Australian Labor Party 2010).

Portfolio oversight of arts and culture had fragmented in the period between Creative Nation and the second cultural policy iteration. The 1993 formation of the Department of Communications and the Arts both reflected and shaped cultural policy at that time. The prior Howard government had continued with this structure for several years. Policy focus on the digital economy, though, saw the subsequent establishment of a Department of Communications, Broadband and the Digital Economy, with arts and cultural heritage moved and separated into other portfolios. In 2010 the Australian Labor Party was returned to national government with the support of independent candidates from rural electorates. The political leverage of the independents led to the establishment of a ministry of regional development in the Prime Minister's office, overseen by former Labor leader Simon Crean. Crean professed a longstanding interest in the arts, and that area was brought into the Prime Minister's portfolio. Subsequent development of the cultural policy occurred there.

The museum sector's disappointment with the Australia 2020 Summit deepened with the release of a cultural policy discussion paper. The document divided cultural activity into three areas: core arts (identified as music, performing arts, literature and visual arts, galleries, libraries, training institutions and cultural venues), creative industries (film and television, broadcasting, electronic games, design and fashion, architecture, publishing, media and advertising), and cultural heritage (instanced only as Indigenous culture). The discussion paper 
reprised the Australia 2020 Summit in emphasizing the visual and performing arts and in its narrow construction of creativity. Museums received almost no recognition. The discussion paper drew some scathing responses, particularly over its narrow conception of cultural heritage. ${ }^{8}$ The Council of Australasian Museum Directors (CAMD) engaged in a furious information gathering project and produced a submission twice the length of the discussion paper. ${ }^{9}$ The submission advanced an argument framed by the UK think-tank Demos, amongst others (Selwood 2009), that collecting institutions were the cultural capital of a creative economy, akin to natural resources of the physical world:

'CAMD would urge that the National Cultural Policy embrace a broader concept of culture which acknowledges the importance to cultural and creative life of "cultural memory" and the heritage collections and organisations which sustain, interpret and develop it.' 10

The museum sector's lobbying raised the profile of museums in the final document, Creative Australia, both in the attention given to museums in the main text, and in the inclusion of an appendix discussing the sector's feedback on the discussion paper. CAMD's concern about the lack of coordination of the museum sector, and its negative impact on the sector's efficiency and accessibility, was supported by Creative Australia's recommendation for a new national coordinating agency.

However, the sector had little impact on the policy's conceptual and structural underpinnings, especially the positioning of culture in Australia's twenty first century political economy. Creative Australia opens with an ominous warning by the arts minister:

The Australian Government has identified a number of areas which are key to increasing jobs, prosperity and productivity as the peak of the investment and resources boom of the early $21^{\text {st }}$ century passes. These are: increasing skills, building a national culture of innovation, investing in infrastructure such as the National Broadband Network, improving regulation and leveraging our proximity to, and knowledge of a rising Asia into a competitive advantage. When you think of these key areas, cultural industries and creative arts skills are central to all (Australian Government 2013:3).

Two things are clear in Creative Australia: it follows a policy trend in conflating culture and the arts, and it focuses on the contribution of the arts and creative industries in the considerable attention it gives to innovation and economic contribution. Creative Australia shares some of Creative Nation's romanticism, especially in its depiction of 'the artist', whose heroic figure is 'central to us as a nation and to securing its future' (Australian Government 2013:2). However, creativity is framed in terms of economic competitiveness. Rhetorically, Creative Australia's appeal to creativity, innovation and productivity, the cluster of concepts at the heart of the productivity narrative, is remarkable, as Table 1 shows. The phrase 'a creative nation is a productive nation' features seven times in the document, visually highlighted to emphasize the message. On one occasion only does Creative Australia associate museums with innovation and productivity, in the context of developing new cultural products or expressions (Australian Government 2013:32). CAMD's submission argued that museums and other public collecting institutions held the cultural resources to contribute to a range of policy priorities, but the sector's contribution to policy agenda and collaboration with other public and private institutions was hampered 'when [cultural] policy is made for the "arts"'11 This fell on deaf ears. As Creative Australia asserts '[c]ulture is more than the arts, but the arts play a unique and central role in its development and expression' (Australian Government 2013: 27).

\section{Rhetorics and Metrics}

Acomparison of keywords in Creative Nation and Creative Australia provides clear evidence that economic productivity is an underpinning theme of Creative Australia, but that it is conceptualized in such a way as to privilege particular forms of cultural activity and constructions of creativity. Conveniently, the documents are approximately the same length, facilitating direct comparison. Using an inductive approach, I chose a set of keywords that respond to three broad themes common to both texts: heritage/identity, cultural forms, and economy/technology. The exercise was controlled to include word-variants (for example, competitive/competition; social/ society). I did not remove institutional titles or programmes, or textual repetition, reasoning that institutions, programmes, and the rhetoric and design of the texts are each significant 
discursive strategies. In the period under scrutiny, some rhetorical changes are predictable, such as the increasing frequency of words associated with digital technologies. However, the table shows clear shifts in policy rhetoric between the two texts. In particular, the profile of heritage declined significantly. The profile of the arts rose dramatically, along with the economic language of innovation, creativity and productivity.

\begin{tabular}{|l|l|l|}
\hline Keyword & Creative Nation & Creative Australia \\
\hline arts & 439 & 835 \\
\hline competition & 15 & 36 \\
\hline cohesion & 0 & 5 \\
\hline creative & 68 & 254 \\
\hline digital & 4 & 95 \\
\hline diversity & 22 & 43 \\
\hline economy & 42 & 153 \\
\hline export & 38 & 16 \\
\hline heritage & 119 & 54 \\
\hline history & 31 & 26 \\
\hline identity & 23 & 27 \\
\hline industry & 115 & 101 \\
\hline innovation & 13 & 87 \\
\hline multicultural & 13 & 3 \\
\hline productive & 2 & 17 \\
\hline social & 32 & 54 \\
\hline technology & 26 & 24 \\
\hline
\end{tabular}

Table 1: Key word frequency analysis of Creative Nation \& Creative Australia

\section{Mobilizing Museums in the Productivity Narrative}

Ideas have careers, as the rise of productivity's career as a core policy concern of Australian governments illustrates.

A number of analysts have cautioned museums and other cultural organizations about the terms in which they engage with such careerism. Selwood (2009:233) suggests that 'the semantics, used to describe museums, galleries and the visual arts' relationship to the creative industries could do with being a little less creative'. Flew (2012:168) singles out the 'overblown' response to the Blair government's demands for cultural organizations to demonstrate their social and economic utility as a pertinent example. Portfolio arrangements and nebulous performance indicators 'generate...a rent-seeking mindset amongst arts and cultural organizations... pitching to whatever are the perceived policy priorities of the day'.

While acknowledging this criticism, entirely resisting the flow of policy is politically naïve and exposes public institutions to charges of special pleading. The pragmatic response of Australian museums to the emergence of multiculturalism in Australian social policy lexicon offers an alternative strategy of engagement. As Jupp (2001:260) notes, multicultural policy in Australia initially showed limited concern with culture in the conventional sense, but focused on settlement programmes and access to public services. The museum sector saw both need and opportunity to intervene in and elaborate multicultural policy, and museums and the 
heritage sector came to occupy an important place in an evolving sense of cultural citizenship, underscoring the principle that newly arrived communities had the right to speak and be heard in the public cultural sphere.

CAMD's response to Creative Australia's discussion paper opted for pragmatism in engaging with the policy career of the cluster of ideas around productivity, innovation and creativity. CAMD argued that museums and other collecting institutions both resourced innovation as the stockholders of the nation's cultural capital and cultural memory, and were innovators in their own right, through institutional developments and programmes. The expanded profile of museums in Creative Australia, in comparison to the discussion paper, can, on the face of it, be seen as evidence of CAMD's successful intervention in policy formation.

However the discursive framing that I have explored in this article gives museums no distinctive place to stand. In this section I want to suggest two conceptual tools that museums might mobilise, to engage with the productivity narrative. The first tool seeks to broaden understandings of innovation in current policy. In the texts discussed in this article, the term is used in the tradition of Schumpeterian or evolutionary economics, pitching economic dynamism and growth through innovation against a static conception of equilibrium economics, within which cultural organizations are compensated on the grounds of market failure and the public good. Schumpeter's work has been conventionally associated with business entrepreneurship, but as we have seen, it now underpins policy support for the creative industries in areas such as digital media, design, and other creative work. In addition to recognising these sectors' contribution to cultural output, Creative Australia sees 'the arts' playing a particular role in forming the human capital required for the sectors' workforces. As we have seen, these areas are considered to be the engines of productivity growth in the knowledge economy, and garner significant policy attention. The contribution of public collecting institutions to disruptive innovation in the digital sphere deserves recognition. The use of social software such as Flickr to enhance collection documentation through user contributions and make collection material available for re-use is one example of a world-wide innovation trend advanced by the sector. A second example is the rapidly expanding use of geo-locative technologies and mobile apps by collecting institutions to interpret urban histories through in situ access to historic photographs. ${ }^{12}$ These developments can be usefully analysed through the creative industries model advanced by Potts et al., particularly in its construction of the 'produser', a figure engaged in both producing and consuming cultural goods. However, these innovations neither preclude public good rationales for funding legacy collections, nor limit our conception of creativity, a concern that is forcefully addressed by Oakley (2009).

A supplementary concept of innovation refers to the use of new resources and institutional alignments to tackle endemic or 'wicked' social and environmental problems that negatively impact social opportunity and cohesion, environmental sustainability, and economic participation. This is often referred to as social innovation, which is defined as: 'a novel solution to a social problem that is more effective, efficient, sustainable, or just than existing solutions and for which the value created accrues primarily to society as a whole rather than private individuals' (Phills et al. 2008).

Some imaginative museum programmes can be analysed from a social innovation perspective. To take an example put forward in the CAMD submission, museum-led social innovation is illustrated by the Australian Museum's Cultural Intervention Program with Diasporific Pacific Islander Young Offenders. The project involved working with juvenile offenders from Pacific Island cultures living in Western Sydney. This group is disengaged from education and employment, and over-represented in crime and imprisonment statistics, with disconnection from cultural support systems hypothesized as one reason why this situation prevails. The Australian Museum used its exceptional collection of Pacific Island material culture to re-connect the young people with their cultural heritage and community in order to assist re-engagement with education and employment pathways. The programme reoriented the museum's collection from its original purpose of documenting an exotic and colonized other, to its use in a social intervention programme involving the creator communities now living in Australia. ${ }^{13}$

The second conceptual tool is the concept of productive diversity. Around the time of Creative Nation's development, in the early 1990s, there was a keen discussion in Australia and elsewhere about the nature of work in culturally diverse, post-industrial societies. This debate 
was focused on skills, communication, cultural respect, and productivity in diverse workplaces (Cope and Kalantzis 1992). As Table 1 indicates, the rhetorical terms in which cultural policy engages with population diversity has changed, illustrated in this example by the usage of 'multiculturalism' and 'cohesion'. However, around $45 \%$ of people living in Australia were born overseas or have a parent born overseas, and an increasing proportion of the Australian workforce is comprised of foreign nationals working here temporarily. Australia is irreducibly culturally diverse and globalized, and in ways that - as Creative Nation observed - extend beyond ethnicity. A broad cultural repertoire is seen as advantageous in a globalizing business environment and in culturally plural societies. Cultural know-how may be as significant as creative know-how (Flew 2012). The recognition in policy documents, such as VenturousAustralia, of the knowledge and creative potential embedded in such populations calls for attention not only to how these assets might be 'leveraged' in a narrow economic sense, but to the wider processes through which inter-cultural dialogue and exchange is facilitated, and social futures are shaped.

\section{Concluding Remarks}

The example of Creative Nation suggests the life of Australia's new national cultural policy may be twenty years rather than the ten years nominated by Creative Australia. The political environment changed with the election in 2013 of a Liberal-National coalition government. The new government incorporated the ministry of arts and culture within the Attorney-General's department. There were early signs that the new bureaucratic arrangements may be unhospitable for the museum sector - the portfolio minister began his career in government with a vigorous campaign to water down Australia's racial vilification laws. The arts and cultural heritage have experienced a wide range of portfolio arrangements since the creation of the first federal arts ministry four decades ago, but the cultural heritage area has lacked the stabilising policy and funding influences of the arms-length Australia Council for the Arts. Homan's (2013) prediction that the incoming government would focus on excellence and the funding of elite arts appeared confirmed by attention to the Australian Ballet School in an otherwise depressing outcome for arts and culture in the 2014 federal budget. If this was an idiosyncratic example, the 2015 federal budget established a National Programme for Excellence in the Arts, re-directing $\$ 110$ million from the Australia Council's peer review funding processes, to be distributed by the portfolio department.

With the incoming government campaigning on economic productivity (Liberal National Coalition 2013), though, the positioning of Creative Australia as a cultural policy for a postresources boom Australia may find support. ${ }^{14}$ Over the next two decades, continuing high levels of immigration to Australia are forecast, particularly to meet skill shortages, and reconciliation with Indigenous people, currently overseen by the Prime Minister, is likely to continue as an ongoing and multi-faceted process. Australian museums, like many international counterparts, have played an important and evolving role in encouraging cross-cultural dialogue and building cultural competency. The opportunity and challenge for the sector is to re-assert this role, and demonstrate its pivotal contribution to innovation and productivity, in the current policy environment.

\section{Notes}

1 Australian Government, Department of Prime Minister and Cabinet (2011) National Cultural Policy Discussion Paperhttp://creativeaustralia.arts.gov.au/assets/national-cultural-policydiscussion-paper.pdf , accessed 30 May 2014.

2 Productivity Commission (2014) Productivity Update, http://www.pc.gov.au/ data/assets/ pdf file/0008/135935/productivity-update-2014.pdf, accessed 6 June 2014. 
3 Szekeres, V. (2011) 'Museums and Multiculturalism - Too Vague to Understand, Too Important to Ignore', in D. Griffin and L. Paroissien, (eds) Understanding Museums Australian Museums and Museology, Canberra: National Museum of Australia, http://nma. gov.au/research/understanding-museums/VSzekeres_2011.html, accessed 23 May 2014.

4 Craik, J. (2007) Revisioning Arts and Cultural Policy - Current Impasses and Future Directions, Canberra: ANU e-Press http://epress.anu.edu.au/anzsog/revisioning/pdf/ whole book.pdf, accessed 4 June 2014.

5 Wood,A. 2007. 'Labor Laws May Undo Howard', The Australian, 5 September 2007 http://www. theaustralian.com.au/news/labor-laws-may-undo-howard/story-e6frg76o-1111114343651, accessed 5 June 2014.

6 National Endowment for Science, Technology and the Arts (2006) The Innovation Gap Why Policy Needs to Reflect the Reality of Innovation in the UK. http://www.nesta.org.uk/ library/documents/Nesta\%20Report\%20TIG.pdf , accessed 5 June 2014.

7 Department of the Prime Minister and Cabinet (2008) Australia 2020 Summit: Final Report. Barton: Department of Prime Minister and Cabinet, p. 1. http://apo.org.au/files/ Resource/2020 summit report full.pdf, accessed 30 May 2014.

8 Morphy, H. (2011) Reponses to the National Cultural Policy Discussion Paper-Australian National University Research School of Humanities and the Arts. http://culture.arts.gov. au/sites/default/files/submissions/Submission\%20292_Redacted.pdf , accessed 23 May 2014.

9 Council of Australasian Museum Directors (CAMD) (2011) Museums, Collections and Australian Culture - A contribution to the development of the National Cultural Policy. http://creativeaustralia.arts.gov.au/assets/council-of-australasian-museum-directors.pdf , accessed 23 May 2014.

10 CAMD (2011), p. 1.

11 CAMD (2011), p. 9.

12 Powerhouse Museum (2015) Powerhouse Museum Walking Tour. http://www. powerhousemuseum.com/walkingtours/ accessed 13 May 2015.

13 Liddell, M., Blake, M., Singh, S., Peita, D., and Heller, E. (2011) 'New Directions for Museums - the Australian Museum's Cultural Intervention Program with Diasporic Pacific Young Offenders in New South Wales', Paper presented to At the Frontier-Museums Australia National Conference, Perth, November 2011. http://museumsaustralia.org.au/ userfiles/file/Conference\%20Papers/2011/2011 Peita.pdf, accessed 3 June 2014.

14 Liberal National Coalition (2013) The Coalition Policy to Boost Productivity and Reduce Regulation, Canberra: Liberal National Coalition. http://lpaweb-static.s3.amazonaws.com/ Policies/ProdPolicy10Jul13.pdf, accessed 5 June 2014.

\section{References}

Australian Government (2013) Creative Australia - National Cultural Policy, Canberra: Australian Government.

Australian Labor Party (2010) Investing in a Creative Australia, Barton ACT: Australian Labor Party. 
Ball, S. (2007) Education plc - Understanding Private Sector Participation in Public Sector Education, London and New York: Routledge.

Banks, M. and O'Connor, J. (2009) 'After the Creative Industries', International Journal of Cultural Policy, 15 (4) 365-73.

Baumol, W. and Bowen. W. (1966) Performing Arts: The Economic Dilemma, New York: The Twentieth Century Fund.

Bennett. T. (2001) 'Introduction' in T. Bennet and D. Carter, (eds) Culture in Australia: Policies, Publics and Programs, 1-9, Cambridge: Cambridge University Press.

Caust, J. (2015) 'Cultural Wars in an Australian Context: Challenges in Developing a National Cultural Policy', International Journal of Cultural Policy, 21 (2) 168-182.

Consultative Committee on Cultural Heritage in a Multicultural Australia (1991) A Plan for Cultural Heritage Institutions to Reflect Australia's Cultural Diversity, Canberra: Australian Government Publishing Service.

Cope, B. and Kalantzis, M. (1992) Productive Diversity, Sydney: Pluto Press.

Craik, J., McAllister, L. and Davis, G. (2003) 'Paradoxes and Contradictions in Government Approaches to Contemporary Cultural Policy: An Australian Perspective', International Journal of Cultural Policy, 9 (1) 17-33.

Cunningham, S. (2009) 'Trojan Horse or Rorschach Blot? Creative Industries Discourse Around the World', International Journal of Cultural Policy, 15 (4) 375-386.

Cutler and Company (2008) VenturousAustralia - Review of the National Innovation System, North Melbourne: Cutler and Company.

Daley, J. (2012) Game Changers- Economic Reform Priorities for Australia, Melbourne: Grattan Institute.

Department of Communication and the Arts (1994) Creative Nation - Commonwealth Cultural Policy, Canberra: Department of Communications and the Arts.

du Gay, P. and Pryke, M. (2002) Cultural Economy - Cultural Analysis and Commercial Life, London: Sage.

Fischer, F. (2003) Reframing Public Policy - Discursive Politics and Deliberative Practices, Oxford and New York: Oxford University Press.

Fischer, F. and Gottweis, H. (eds) (2012) The Argumentative Turn Revisited - Public Policy as Communication Practice, Durham NC: Duke University Press.

Flew, T. (2012) The Creative Industries - Culture and Policy, London: Sage.

Garnaut, R. (2013) Dog Days - Australia After the Boom, Collingwood Vic.: Redback.

Garnham, N. (2005) 'From Cultural to Creative Industries', International Journal of Cultural Policy, 11(1) 15-29.

Gibson, L. (2001) The Uses of Art - Constructing Australian Identities, St Lucia: University of Queensland Press.

Gill, R. and Pratt, A. (2008) 'In the Social Factory? Immaterial Labour, Precariousness and Cultural Work', Theory, Culture and Society, 25 (7-8) 1-30. 
Glow, H. and Johanson, K. (2006) 'Looking for Cultural Value - Critiques of Australian Cultural Policy', Asia Pacific Journal of Arts and Cultural Management, 4 (2) 259-69.

Grodach, C. and Silver, D. (2013) The Politics of Urban Cultural Policy - Global Perspectives, London and New York: Routledge.

Hage, G. (1998) White Nation - Fantasies of White Supremacy in a Multicultural Society, Annandale NSW: Pluto Press.

Hartley, J. (ed.) (2005): Creative Industries, Malden MA: Blackwell.

Hawkins, G. (1993) From Nimbin to Mardi Gras - Constructing Community Arts, St Leonards NSW: Allen and Unwin.

Heilbrun, J. (2003) 'Baumol's Cost Disease', in Towse, R. (ed.) A Handbook of Cultural Economics, 91-101, Cheltenham: Edward Elgar.

Hodge, B. and O'Carroll, J. (2006) Borderwork in Multicultural Australia, Crows Nest:Allen and Unwin.

Homan, S. (2013) 'From Coombs to Crean: Popular Music and Cultural Policy in Australia', International Journal of Cultural Policy, 19 (3) 382-98.

Industries Assistance Commission (1976) Assistance to the Performing Arts, Canberra: Australian Government Publishing Service.

Jupp, J. (2001) 'The Institutions of Culture - Multiculturalism' in In D. Bennett and D. Carter, (eds) Culture in Australia - Policies, Publics and Programs, 259-77, Cambridge: Cambridge University Press.

KPMG Econtech (2010) Measuring the Impact of the Productivity Agenda - Final Report, Canberra: Department of Education, Employment and Workplace Relations.

Lash, S. and Urry, J. (1994) Economies of Signs and Space, London: Sage.

Macdonnell, J. (1992) Arts, Minister? Government Policy and the Arts, Sydney: Currency Press.

McShane, I. and Thomas, J. (2010) 'Unlocking the Potential? Australia's Digital Strategy and Major Public Libraries', Prometheus - Critical Studies in Innovation, 28 (2) 149163.

Message, K. (2011) 'Slipping Through the Cracks - Museums and Social Inclusion in Australian Cultural Policy Development 2007-2010', International Journal of Cultural Policy, 19 (2) 201-21.

Miller, T. (2009) 'From Creative to Cultural Industries', Cultural Studies, 23 (1) 88-99.

O'Connor, J. (2009) 'Creative Industries - a New Direction?', International Journal of Cultural Policy, 15 (4) 387-402.

Oakley, K. (2004) 'Not So Cool Britannia: The Role of the Creative Industries in Economic Development', International Journal of Cultural Studies 7(1) 67-77.

(2009) 'The Disappearing Arts: Creativity and Innovation after the Creative Industries', International Journal of Cultural Policy 15 (4) 403-13.

Phills, J., Deiglmeier, K. and Miller, D. (2008) 'Rediscovering Social Innovation', Stanford Social Innovation Review, 6 (4) 10-13. 
Potts, J. (2014) 'New Technologies and Cultural Consumption', in Ginsburgh, V. and Throsby, D. (eds) Handbook of the Economics of Arts and Culture Vol. 2, 215-40, Oxford and San Diego: North Holland.

(2011) Creative Industries and Economic Evolution, Cheltenham UK and Northampton MA: Edward Elgar.

Potts, J. and Cunningham, S. (2008) 'Four Models of the Creative Industries', International Journal of Cultural Policy, 14 (3) 233-247.

Potts, J., Cunningham, S., Hartley, J. and Ormerod, P. (2008) 'Social Network Markets - a New Definition of the Creative Industries', Journal of Cultural Economics, 32, 167-85.

Pratt, A. (2005) 'Cultural Industries and Public Policy', International Journal of Cultural Policy, 11 (1) 31-44.

Productivity Commission (2006) Conservation of Australia's Historic Heritage Places Productivity Commission Inquiry Report No. 37, Canberra: Productivity Commission.

Rowse, T. (1985) Arguing the Arts, Ringwood: Penguin.

Selwood. S. (2009) 'Creativity and Innovation in the Cultural Economy: Museums, Galleries and the Visual Arts", in Pratt, A. and Jeffcut, P. (eds) Creativity, Innovation and the Cultural Economy, 219-240, London and New York: Routledge.

Stevenson, D. (2000) Art and Organisation: Making Australian Cultural Policy, St. Lucia: University of Queensland Press.

Throsby, D. (2006) Does Australia Need a Cultural Policy? Platform Papers No. 7, Sydney: Currency Press.

*Ian McShane is a senior research fellow in the Centre for Urban Studies, RMIT University, Melbourne, Australia. He has a background as a museum curator and public sector manager. His research spans historical and policy studies, with a focus on urban management, cultural organizations and educational institutions.

\section{Address}

Centre for Urban Research,

RMIT University,

GPO Box 2467, Melbourne, Victoria, 3001,

Australia

Ph 61399258236

Fax 61399259888

ian.mcshane@rmit.edu.au 